\title{
Hidden Power Shifts: Multilevel Governance and Interstitial Institutional Change in Europe
}

\author{
Adrienne Héritier
}

\section{INTRODUCTION}

Substantial institutional changes, institutions defined as rules of behaviour (North 1990), occur not only in open arenas meant to design and negotiate formal institutional changes. Rather they also happen interstitially between these salient events, in a covert way leading to informal institutional changes which, however, may considerably change the institutional status quo. Which are the underlying causal mechanisms of interstitial institutional changes, and, in particular, how are they influenced by a multilevel context in which actors are negotiating informal institutional changes? Arthur Benz (1992, 2009, 2016) has argued that the dynamics of multilevel governance and multi-arena governance offers new opportunities and limitations in a formal bargaining process. However, the same dynamics offer also additional opportunities and restrictions for actors to strengthen their power in the re-negotiation

\section{A. Héritier (田)}

European University Institute, Florence, Italy

e-mail: Adrienne.Heritier@EUI.eu

(C) The Author(s) 2019

N. Behnke et al. (eds.), Configurations, Dynamics and Mechanisms

of Multilepel Gopernance, Comparative Territorial Politics,

https://doi.org/10.1007/978-3-030-05511-0_19 
of incomplete institutional rules. Incomplete formal institutional rules are renegotiated in the course of their application and lead to informal institutional rules. This can also be observed in the case of the European Parliament (EP) when seeking to extend its powers under institutional rules. Which typical patterns can we identify and which are the factors of success and failure when the EP used strategies across levels and are nas to bring about informal institutional changes in its favour? The article shows that in three cases of European politics, the nomination and investiture of the Commission President, the nomination and investiture of individual Commissioners and the Transatlantic Trade and Investment Partnership (TTIP), the EP's use of multilevel strategies and crossarena strategies brought about an interstitial institutional change in its favour. The article first develops the theoretical argument and a num ber of hypotheses, secondly, describes the methodology used in order to empirically assess the plausibility of the hypotheses. It thirdly presents the empirical material in the three cases and concludes by assessing the valid ity of the hypotheses in the light of the empirical material.

\section{Theoretical Argument: Changing Institutional Rules: \\ A Rationalist, Power-Based Bargaining Explanation of Informal Institutional Change}

To explain informal empowerment of the EP, we base our argument on a rational institutionalist bargaining theory of institutional change (Héritier $2007) .{ }^{1}$ At the micro-level, it is assumed that actors are boundedly rational and do not have perfect information because there are cognitive limits to and transaction costs of information collection. It is further assumed that actors seek to maximise their institutional power in order to increase their influence over policy outcomes. At the macro-level, it is assumed that actors interact in a given institutional context, in this particular case in a multilevel institutional context and a multi-arena context at the same level. These decision-making processes are subject to specific decision-making rules, such as unanimity rule or majority rule. Moreover, the dynamics of multilevel governance are compounded by the fact, as Benz

${ }^{1}$ Authors share similar assumptions of rational behaviour to explain the empowerment of the EP. However, their work focuses exclusively on the role of member states in the shaping of formal treaty rules. By contrast, we focus on the role of the EP in changing formal and informal institutional rules. has elaborated in his work, that at one and the same level various actors' decisions need to be coordinated, before interacting with other actors at the higher level. This leads to a complex web of sequential interactions between actors across levels, but also at the same level that needs to be accommodated in order to come to a decision. Institutions are defined as sets of man-made rules of behaviour that facilitate and restrict social interaction (North 1990). They guide interaction in the accomplishment of joint tasks, such as legislation. The existing rules allow the actors involved to incorporate the expectations of the actions of other involved actors into their own decision-making (Lake and Powell 1999). This is because these actors assume that the other actors will more or less abide by the existing rules in order to avoid sanctions. Institutional rules, therefore, constitute an important source of information in forming expectations as to how other actors are likely to behave.

Given bounded rationality and the transaction costs of information collection, negotiation and monitoring of contract compliance, these institutional rules are assumed to constitute incomplete contracts which will be subject to re-negotiation in the course of their application. We specifically focus on the question of what the distributional implications of institutional rules are, how a change of rule comes about, who it favours and who it does not, how it shapes the strategic preferences of actors and how this fact affects the further re-negotiation of the rule. These theoretical considerations are applied to analyse the strategies used by the EP to bring about an alteration of pre-existing formal rules in the course of their application, giving rise to new informal institutional rules that extend the powers of the EP. We define an informal institutional rule as one that is not subject to formal third party dispute resolution or formal sanctioning, usually not written down and developed outside the formal decision-making channels (Farrell and Héritier 2003, 2007a, b).

\section{Interstitial Institutional Change:}

\section{The Emergence of Informal Institutions}

Starting from the above assumptions of actors' bounded rationality, we argue that formal institutional rules mostly are incomplete contracts ${ }^{2}$

${ }^{2}$ Assuming bounded rationality implies that when actors design institutional rules (contracts), they are unable to take into account every relevant contingency. Decisions are time-consuming and costly. 
(Héritier 2007; Farrell and Héritier 2003, 2004, 2005, 2007a, b; Stacey and Rittberger 2003). The incompleteness of contracts/institutional rules flows from the high costs of collecting information on possible circumstances of contract application, but also from the diversity of interests and high transaction costs of the actors negotiating the initial formal institutional rule. Actors often settle for quite vague rule formulations in order to save the transaction costs of negotiating, and-given diversity of preferences - to allow for an agreement at all. As a result and due to the ambiguity of the institutional formal rule and possible external events, the formal rule will be subject to renegotiation in the course of its application and this may therefore give rise to an informal institutional rule.

The new informal institutional rules emerging in the course of the rule application of the formal initial rule may serve merely to increase efficiency, i.e. reduce the transaction costs in the application of the rule for all concerned. Alternatively, the new informal institutional rule may imply a relative power shift in the position of the actors involved. Here the focus rests on the informal institutional rules which imply a power shift between actors.

The redefinition of the initial formal rule takes the form of an implicit bargaining process and its outcome reflects the relative power of the actors involved. Two factors determine the relative power of actors. Firstly, their formal institutional positions in the decision-making process at tl which defines an actor's competences and thereby influences the actor's ability to credibly threaten specific kinds of action, such as the unanimity rule purveying the right of veto to every actor. Further institutional conditions of decision-making, described above, may also determine the outcome of the bargaining process; for example, whether decision-making occurs in arenas across multiple levels or whether there is a multiple-issue- or a single-issue-agenda etc. Second, an actor's availa ble fall-back position, should negotiations fail, will determine its relative power when negotiating an informal rule. The longer the time horizon of an actor, the lower the intensity of its preferences, the more powerful it will be in the bargaining process. Patience enables it to make credible threats with regard to one or more items of negotiation in order to enhance its overall position in the bargaining process (Knight 1995 Elster 1989; Luce and Raiffa 1957; Nash 1953). Given specific actors' preferences, the institutional conditions at $t 1$, the available fall-back position of actors will determine the distributive outcomes of the (implicitly) negotiated informal institutional rule which will specify the initial formal
ambiguous rule.

\section{The EP's Strategies to Obtain Informal Institutional Changes}

How can we explain an informal institutional change in favour of one specific actor? Or more specifically, how can we explain how in a context of multilevel governance, as analysed in the context of Arthur Benz' work, that the EP can obtain an informal change of an institutional rule in its favour? If issues are negotiated in more than one aren $a^{3}$ and level at one point in time, the EP may use a strategy which links the two arenas in order to seek an advantage for itself in one arena. The EP has a more favourable opportunity structure.

This is the so-called arena-linking strategy, a strategy that is frequently used by the EP. Assuming decision-making close in time in (at least) two political arenas at the same or different levels, we argue that the renegotiation of an existing formal institutional rule can be influenced by the establishment of a link between the two arenas. The EP with limited or no competences in one arena can withhold its support for a decision in another arena at the same level, where it has full competences until it obtains more informal institutional powers in the arena with limited or no competences. In simple terms: one arena is taken hostage in order to obtain more institutional power in another arena. However, this strategy will only be successful if the gains of the EP's acquiescence in the one arena outweigh the loss incurred by the other actors by an informal institutional power gain of the EP in the other arena. Therefore we submit:

\section{H1: Linked-arenas hypothesis}

"If the most powerful actors' gains from an agreement in arena $Y$ outweigh the costs of accommodating the EP's preferences in arena $X$, the $E P$ obtains an (in)formal institutional change in its favour by linking

${ }^{3}$ An arena is a formal decision-making setting with its formally competent decision makers deciding on an issue or a number of issues at a specific point in time. In our cases we focus on a treaty shaping arena and an intergovernmental arena. In other work we focused on legislative arenas deciding under co-decision on legislative issues. 
its formal veto in arena $\mathrm{Y}$ to an (in)formal institutional concessions in arena X."

Another across-levels and across-arena strategy used by the EP to increase its informal institutional power is to take "unilateral action" and act as " "first mover" across levels and across arenas in such a way as to foreclose specific institutional options to the other actors involved, or to at least render the reversal of the first move at $t 2$ very costly. By introducing an informal institutional innovation with respect to the other involved actors, it may create institutional "facts" that may turn out to be costly to reverse by the other actors.

Just to give two examples of important institutional innovations unilaterally introduced by the EP: the EP's nominating and electing of a Commission President; and the EP introducing hearings for individual Commissioners proposed by member governments. We therefore claim:

H2: Unilateral action or 'first-mover' hypothesis

"If the costs of returning to the status quo ante are high, the EP obtains an (in)formal institutional change in its favour by taking the first move to unilaterally invent and implement a new rule."

Another, frequently employed strategy by the EP in a multilevel and multiple arena structure is to lobby and mobilise external political and societal actors at the European level or the international level. It would form informal alliances with them, in order to pursue its goals of informal institutional empowerment in the European context. Hence, we submit:

H3: Mobilising external actors hypothesis

"If there are powerful and common-good oriented actors, who are generally in favour of empowering the EP, the latter may obtain an informal institutional change in its favour by mobilizing these actors, if these actors influence the formal decision-makers so as to empower the EP."

In the following these three hypotheses will be empirically assessed in three empirical cases, the nomination of the EU Commission President, the nomination and confirmation of individual Commissioners and the TTIP agreement. We argue that the choice of strategy by the EP is guided by the fact whether preconditions are the causes favouring a successful application of a strategy given at the point of action. We also show in the three cases under empirical scrutiny that strategies may be combined.

\section{The Empirical Cases}

\section{Methodology}

In order to empirically assess the hypotheses, we use the congruence method in combination with process-tracing (George and Bennett 2005, pp. 181, 121). The congruence method starts from a theoretical argument, as developed in the theory part. First, it is identified which of our factors favouring the successful use of an EP strategy leading to an empowerment of the EP are found in each case study. When the hypothesized conditions are found it is investigated whether the expected outcome (informal institutional change in favour of the EP) is given. In order to identify the causal mechanism (i.e. the strategies applied) that are posited to lead to a change in informal institutional power, the method of process tracing (George and Bennett 2005) is used to identify causality in addition to congruence between the hypothesised cause or condition and the explanandum, which could, in principle, be pure coincidence (Héritier 2008, pp. 69-72). The three hypotheses regarding EP strategies used in order to extend its informal institutional power are discussed in three cases. Data is collected using a triangulation of methods. We analysed official documents and press material, conducted five semi-structured interviews with EU officials, analysed quantitative data if relevant, and used secondary literature.

\section{Case One: The Spitzenkandidaten Strategy ${ }^{4}$}

By opting for the "Spitzenkandidaten Strategy" in the nomination of the Commission President, the EP pre-empted member states' actions and thus prevailed in the interpretation of the corresponding treaty provision as to how to select a Commission President. It offers a confirmation of the unilateral action or 'first-mover' bypothesis: "If the costs of returning to the status quo ante are high, the EP obtains an (in)formal institutional change in its favour by taking the first move to unilaterally invent and implement a new rule" (H2).

The Lisbon Treaty stated that: "taking into account the elections to the European Parliament and after having held the appropriate 
consultations", the European Council "proposes to the European Parliament a candidate for President of the Commission [...] [who] shall be elected by the European Parliament by a majority of its component members"

At the Warsaw Council in December 2010, the PES (Party of European Socialists) decided to exploit the ambiguity introduced by the term 'election' in the Lisbon Treaty to nominate a candidate from their party for the post of President of the European Commission although the Treaty clearly states that the candidate is to be proposed following member states' proposals by the European Council. Nonetheless, the Commission was supportive of other political parties following this move of the PES. In his State of the Union Address before the EP in September 2012, the President of the Commission, Barroso, stated that "an important means to deepen the pan-European political debate would be the presentation by European political parties of their candidate for the post of Commission President at the European Parliament elections already in 2014" (Barroso, State of the Union Address, 2012). Very likely the reason for this support from the Commission is that it would see its own legitimacy enhanced if its President were picked and directly elected by the EP, i.e. the only EU institution directly elected by citizens.

In November 2012 , the EP, in another unilateral move, voted for a resolution on elections to the EP in 2014 in which it urged "the European political parties to nominate candidates for the Presidency of the Commission and expect those candidates to play a leading role in the parliamentary electoral campaign in particular by personally presenting their programme in all Member States of the Union" (Hobolt 2014, p. 1532).

The then President of the EP, Martin Schulz and the EP Secretary General, Klaus Welle, were very active in promoting such a strategy. For example, the Secretary General observed in September 2013 that: "[P] eople are now finding out - to their astonishment - that [...] the Lisbon Treaty has very much changed the legal basis for the process on how to get the Commission into office. First, the EP 'elects' - not simply 'approves' - the Commission President. Second, the European Council selects its nominee for President based on the outcome of the European elections" (Welle 2013, cited by Dinan 2014).

In a non-binding resolution on "Improving the practical arrangements for the holding of the European elections in 2014" (EP Report 2013 regarding 2014 elections), the EP set out to define practical details of the desired new arrangements. It called for political parties to nominate their candidates for Commission President sufficiently early to ensure they would be able to promote a pan-European campaign. It also asked the European Council to first consider the candidate put forward by the European political party that wins most seats in the elections. Accordingly, Schulz was confirmed as candidate for the European Socialist Party in 2013 and four of the six European parties followed its lead and selected their own candidates for Commission President in early $2014 .^{5}$

Some member states, in particular Germany and the UK as well as other national leaders, together with the President of the European Council, Herman Van Rompuy, initially voiced their disagreement with the EP's interpretation of the Treaty provision and nominating its own candidates.

Yet, after several parties had selected their candidates, it became increasingly difficult for heads of states to push the EP initiative back and propose an alternative candidate for presidency. Individual potential national candidates were wary when considering the risk of running against a candidate supported by an EP majority. Moreover, in Germany, Chancellor Merkel was pressured by MEPs from her own party and her SPD junior partner. This illustrates how the EP's unilateral action had greatly increased the costs of returning to the status quo ante for member states. After the elections in May 2014 that gave the EPP a majority, it was agreed by the leaders of the four political groups that had put forward candidates to ask the European Council to invite Jean Claude Juncker to be a candidate for the post of President of the Commission. This proposal was backed by the European Council, with finally only the UK and Hungary voting against (Peterson 2017). In June 2014, JeanClaude Juncker was elected by the EP by the Alliance of Liberals and Democrats for Europe, and some of the European Socialists and Greens. The Heads of State and Government obliged, but only after the unprecedented move of the two countries that had opposed his nomination explicitly requesting a vote and voting negatively.

${ }^{5}$ The Eurosceptic right-wing Euro-parties, the Alliance of European Conservatives and Reformists (AECR) and the Movement for a Europe of Liberties and Democracy did not nominate any candidate. 
The creation of this new rule is a clear confirmation of the 'firstmover hypothesis' ( $\left.\mathrm{H}_{2}\right)$ : If the costs of returning to the status quo ante are high, the EP obtains an institutional change in its favour. The con gruence test shows that in view of high costs of returning to the status quo ante, member states accepted the informal institutional power gain obtained by the EP.

\section{Case Two: The European Parliament's Informal Voice} in Appointing Individual Commissioners

Again, through a strategy of a unilateral move (H2) introducing an informal institutional rule of organizing hearings for Commissioners proposed by member states, and linking its approval of individual proposals to its right of confirming the Commission in its entirety (arena linking $\mathrm{H1}$ ), the EP created for itself an informal de facto power of appointing individual Commissioners.

In the follow up to the Maastricht treaty, the EP unilaterally introduced a new internal rule of procedure prescribing that prior to EP voting for the investiture of the Commission as a collective body, it would organize confirmation hearings for individual nominees of Commissioners. The latter would be asked to appear before the responsible committees of the EP where they would make a statement and answer questions. Based on these hearings, the committee would then report its conclusions to the President of the EP (Jacobs 1995, p. 6). This provision was contested by the outgoing Commission (Interview 1-4.2, Interview 2-4.2). Nonetheless, the EP made it explicit that it simply would not schedule a vote on the new Commission in its entirety until the Commission had complied with this requirement (Commission Service, internal note, 1994). The Santer Commission therefore agreed to go through the procedure, which in turn required a prior accord on the distribution of portfolios. MEPs strongly criticised the performance of some candidates, but rather than rejecting the Commission as a whole, MEPs pressed for a reallocation of responsibilities. Following Jacques Santer's resignation and prior to the vote on his successor, the EP obtained the concession from the Commission President that he would consider asking for the resignation of any Commissioner in whom the EP expressed a lack of confidence (Nugent 2001, p. 86; Judge and Earnshaw 2002). Accordingly, in 2004, the EP started to conduct public hearings of Commissioner nominees and has done so ever since.
This rule of informal individual censorship was included in an interinstitutional agreement in November 2010 (EP and EC, framework agreement, 2010). Therefore, the EP successfully created two new informal institutional rules to its advantage: the rules to hold individual hearings of Commissioners in order to judge their competencies, and to reserve the right to ask the Commission President to reshuffle or replace some members of his/her team. From the perspective of our general argument, this success is the result of a strategy of first mover (H2) and arena linking ( $\mathrm{H1})$ : The EP created a new arena of hearings of individual Commissioner nominees (first mover strategy $\mathrm{H} 2$ ) and linked it to the arena of its competence of confirming the Commission in its entirety $(\mathrm{HI})$.

$$
\text { i }
$$

\section{Case Three: The Transatlantic Trade} and Investment Partnership (TTIP) ${ }^{6}$

The TTIP negotiations in an intergovernmental arena were launched in July 2013. After fifteen bargaining rounds between the EU and US there was no concrete outcome. In spite of the current stalemate due to the US President Trump's intervention, the TTIP negotiations have fundamentally changed the EP's informal institutional involvement in the negotiation of international agreements that fall under the ordinary legislative procedure (Interview 11). The EP has never been included so extensively in negotiations and there has never been so much collaboration between the Commission and the EP during the course of trade talks (Interview 11). What the EP aspired to obtain in this process included access to all negotiation documents and being involved in the negotiation mandate. Furthermore, the EP wanted negotiation documents to be made accessible to all MEPs, and not just those in relevant parliamentary committees.

The EP was successful in reaching informal institutional change in its favour by applying two strategies, unilateral action (H2) and mobilizing external actors with similar preferences over outcomes (H3).

In May 2013, the EP, moving fast, released a resolution before the Council had authorised the Commission's negotiation mandate. More specifically, the EP made its resolution public before the Council Working

${ }^{6}$ This section is based on Hériter et al. (2018). 
Group and discussed the negotiation directives (Interview 13). The resolution underlined the EP's request to have access to and a say in the negotiation mandate. The Commission acknowledged the EP's requests so that the parliamentary resolution served as a de facto negotiation mandate by the EP (Interview 13). When the Commission launched the TTIP negotiations, it took into account the EP's position on the mandate (Interview 13). But also the Council preferred to coordinate with the EP when defining the negotiation directives in order to avoid an eventual rejection of TTIP (Interview 14). This was a huge success for the $\mathrm{EP}$ and led to its informal institutional empowerment as its long-stand ing demands were met. Thus, in the case of TTIP, the EP informally coauthorised the Commission's negotiation mandate. The EP would be on equal footing to the Council if this were formalised and, indeed, this is what some MEPs have recently requested (Interview 11, 12, 13). Hence by using this first-mover strategy across levels with respect to the member states defining their negotiation mandate for the Commission, the $\mathrm{EP}$ was successful in increasing its informal institutional power. Rejecting this informal involvement of the EP in defining the negotiation man date would have jeopardized the negotiations with the counterpart. The necessities of transatlantic across arena decision-making exerted pressure on the Commission and the Council to accept the EP's pressure to expand its informal institutional powers in the European arena.

In another unilateral move, the EP took the unusual step of establishing a direct link to the negotiating counterpart. It set up parliamentary sessions and hearings with guests from the US delegation (Interview 12). Some MEPs also had direct meetings with American officials in Washington to discuss the TTIP negotiations (Interview 12). Although these meetings mainly revolved around gathering more information on the negotiations (Interview 13), in fact, the EP unilaterally invented the rule of talking directly to the negotiating counterpart. Even though these direct meetings between the EP and the US do not have the status of fully-fledged negotiations, they represent a big step towards further empowering the EP as they provide it with the informal institutional power to talk directly with the negotiation partner. It would be difficult for the Commission to prevent the EP from unilaterally setting up meetings with the negotiation partner as this would incur very high costs in terms of time, staff and public credibility as well as possible retributions from parliamentarians; the EP's move to invite representatives from the US delegation can therefore be qualified as unilateral action.
Moreover, to obtain more institutional power with respect to access to negotiation documents, the EP used a mobilisation strategy of external actors with similar preferences over outcomes, in particular the European Ombudsman, as well international Civil Society Organisations. Hence it used a cross-arena and cross-level strategy to reinforce its attempts at informal institutional change. As claimed in $\mathrm{H} 3$ : If there are powerful and common-good oriented actors, who are generally in favour of empowering the EP, the latter may obtain an informal institutional change in its favour by mobilizing these actors. The underlying causal mechanism is that these actors successfully pressure the formal decisionmakers to empower the EP.

The EP demanded access to all negotiation documents and that they are made available to all MEPs, and not just those in relevant parliamentary committees and the rapporteurs. This request resonated with one of the most important concerns raised publicly regarding TTIP, i.e. a lack of transparency. Civil society organisations demanded public access to the EU's negotiation documents. Echoing public demands, the EP wanted the Commission to make documents co-authored by the US accessible, i.e. extending public access to documents to those of the negotiation partner (Interview 13). The EP literally stated in its resolution that the Commission should translate its "transparency efforts into meaningful practical results, inter alia by reaching agreements with the US side to improve transparency, including access to all negotiation documents for the Members of the European Parliament, including consolidated texts" (EP 2015a, Art. ii).

In order to pressure the Commission into the above measures, the EP mobilised third actors in favour of empowering the EP, more specifically, like-minded civil society organisations and the European Ombudsman (Crisp 2014). The European Ombudsman, in particular, had the necessary organisational resources and legitimation to add weight to the EP's demand. The EP used the support of like-minded NGOs and of the European Ombudsman to back its position on TTIP's transparency over eleven months of informal negotiations with the Commission (EP 2015b).

First, the European Ombudsman launched a public consultation on TTIP's transparency to which it received 315 submissions (Ombudsman 2014). Based on this public consultation, the European Ombudsman then opened an own-initiative inquiry in 2014 addressing the Commission's efforts to make TTIP more accessible and transparent 
(Ombudsman 2014). In addition to this own-initiative inquiry, civil society organisations and MEPs filed a complaint to the European Ombudsman regarding the secrecy of the Commission's negotiation documents (Crisp 2014). However, the European Ombudsman found no maladministration in this investigation because the Commission had already replied and improved measures based on the earlier own-initiative inquiry (Ombudsman 2015). Further to this, the EP joined in with citizens' demands for more information on TTIP on the occasion of civil society organisations sending thousands of automated emails to the Commission to complain about the lack of transparency (Interview 11).

The mobilisation strategy was a success. In December 2015, the EP issued a statement that all MEPs had access to all categories of confidential documents relating to TTIP, including consolidated texts that reflect positions by the US (EP 2015b). "As a result of pressure from the European Parliament, the European public and the EU Ombudsman, the European Commission introduced a "transparency initiative", during the TTIP talks, which made an unprecedented number of documents available" (EP 2015b, italics as in original). The EP interpreted these new access rules as a precedent for the transparency of future international agreement negotiations (EP 2015b). The new rules resulted in the wellknown 'reading room', where all MEPs can consult classified documents (Interview 11). They also now have access to limited documents through a newly established database (Interview 13). Never before had the EP been so well informed and this was also achieved through the mobilisation of the public and European Ombudsman on the issue of transparency. Thus, this provides confirmatory evidence of our mobilisation hypothesis $\mathrm{H} 3$.

Overall, the EP's involvement in the TTIP negotiations was much greater than in earlier negotiations and it obtained significant informal institutional powers in the definition of the negotiation mandate and in having access to negotiating documents.

\section{CONCLUSION}

How can the theory of multilevel and multi-arena governance be fruit fully linked to the theory of interstitial institutional change? The article develops a number of hypotheses linking the two approaches in order to show how the combination of the two can offer new perspective on how actors can take advantage of multilevel and multi-arena governance to expand their institutional power interstitially. Arthur Benz in his work (Benz 1989, 1992, 2009, 2016) very compellingly developed the dynamics of multilevel and multi-arena governance and the opportunities and restrictions they constitute for bargaining processes. Linking his theoretical arguments to the bargaining dynamics of interstitial informal institutional change allows to gain additional insights on how actors can change the institutional status quo. These processes normally remain hidden if concentrating exclusively on the reforms of formal rules at one level.

\section{REFERENCES}

Barroso, J. M. D. (2012). State of the Union (2012): José Manuel Durão Barroso, President of the European Commission. State of the Union.

Benz, A. (1989). Intergovernmental Relations in the 1980s. Publius: The Journat of Federalism, 19(4), 203-220.

Benz, A. (1992). Politik in Mebrebenensystemen. Wiesbaden: Springer.

Benz, A. (2009). Politik in Mehrebenensystemen. Springer.

Benz, A. (2016). Constitutional Policy in Multilevel Government: The Art on Keeping the Balance. Oxford: Oxford University Press.

Benz, A., Scharpf, F. W., \& Zintl, R. (1992). Horizontale Politikverflechtung. Zur Theorie pon Verbandlungssystemen. Frankfurt and New York: Campus.

Crisp, J. (2014). EU Ombudsman Demands More TTIP Transparency. http:/ /www.euractiv.com/sections/trade-industry/eu-ombudsman-demands-more-ttip-transparency-303831. Accessed 9 March 2015.

Dinan, D. (2014). Governance and Institutions: The Unrelenting Rise of the European Parliament. Journal of Common Market Studies, 52(S1), 109-124.

Elster, J. (1989). Nuts and Bolts for the Social Sciences. Cambridge: Cambridge University Press.

EP. (2015a). European Parliament Resolution of 8 July 2015 Containing the European Parliament's Recommendations to the European Commission on the Negotiation for the Transatlantic Trade and Investment Partnership (TTIP). http://www. europarl.europa.eu/sides/getDoc.do?pubRef $=-/ / \mathrm{EP} / / \mathrm{TEXT}+\mathrm{TA}+\mathrm{P} 8-\mathrm{TA}$ 2015-0252+0+DOC+XML+V0//EN. Accessed 4 October 2016

EP. (2015b). All MEPs to Hape Access to All Confidential TTIP Documents. http:/ / www.europarl.europa.eu/sides/getDoc.do?type=IM-PRESS\&reference $=20151202$ IPR 05759 \&language $=\mathrm{EN} \&$ format $=\mathrm{XML}$. Accessed 4 October 2016.

Farrell, H., \& Héritier, A. (2003). Formal and Informal Institutions Under Codecision: Continuous Constitution Building in Europe. Gopernance, 16(4), $577-600$. 
Farrell, H. \& Héritier, A. (2004). Interorganizational Negotiation and Intraorganizational Power in Shared Decision Making: Early Agreements Under Codecision and Their Impact on the European Parliament and Council. Comparative Political Studies, 37(10), 1184-1212.

Farrell, H., \& Héritier, A. (2005). A Rationalist-Institutionalist Explanation of Endogenous Regional Integration. Journal of European Public Policy, 12(2) 273-290.

Farrell, H. \& Héritier, A. (2007a). Introduction: Contested Competences in the European Union. West European Politics, 30(2), 227-243.

Farrell, H., \& Héritier, A. (2007b). Codecision and Institutional Change. West European Politics, 30(2), 285-300.

George, A. L., \& Bennett, A. (2005). Case Studies and Theory Development in the Social Sciences. Cambridge: MIT Press.

Héritier, A. (2007). Explaining Institutional Change in Europe. Oxford: Oxford University Press.

Héritier, A. (2008). Causal Explanation. In D. della Porta \& M. Keating (Eds.) Approaches and Methodologies in the Social Sciences: A Pluralist Perspective (pp. 61-80). New York: Cambridge University Press.

Héritier, A., Meissner, K. L., Moury, C., Schoeller, M. (2018) Parliamentarisation from the Top? Success and Failure in Empowering the European Parliament.

Héritier, A., Moury, C., Schoeller, M., Meissner, K. L., \& Mota, I. (2015). The European Parliament as a Driving Force of Constitutionalisation. Brussels: European Parliament.

Hobolt, S. B. (2014). A Vote for the President? The Role of Spitzenkandidaten in the 2014 European Parliament Elections. Journal of European Public Policy, $21(10), 1528-1540$

Interview 1 ET. (2015, February 2). European Commission. Brussels, Belgium. Interview 11 ET (2015, February 26). European Parliament. Brussels, Belgium. Interview 12 ET, (2015, February 27). European Parliament. Brussels, Belgium. Interview 13_ET. (2015, February 27). European Commission. Brussels, Belgium.

Interview 14 ET. (2015 February 27). European Commission. Brussels, Belgium.

Jacobs, F. (1995). The European Parliaments Role in Nominating the Members of the Commission: First Steps Towards Parliamentary Gopernment or Us Senate-Type Confirmation Hearings. http://aei.pitt.edu/6950/. Accessed 6 Senate-Type Confirm
November 2017.

Knight, J. (1995). Models, Interpretations and Theories: Constructing Explanations of Institutional Emergence and Change. In I. Knight \& I. Sened (Eds.), Explaining Social Institutions (pp. 95-120). Ann Arbor: Michigan University Press.
Lake, D. A., \& Powell, R (1999). Strategic Choice and International Relations. Princeton: Princeton University Press.

Luce, D. R, \& Raiffa, H. (1957). Games and Decisions: Introduction and Critical Surpey. New York: Dover Publications.

Nash, J. F. (1953). Two-Person Cooperative Games. Econometrica, 21, 128-140.

Nugent, N. (2001). The European Commission. Basingstoke: Palgrave.

Ombudsman. (2014). Decision of the European Ombudsman Closing Her OwnInitiatipe Inquiry OI/10/2014/RA Concerning the European Commission. http://www.ombudsman.europa.eu/en/cases/decision.faces/en/58668/ html.bookmark. Accessed 4 October 2016.

Ombudsman. (2015). Decision of the European Ombudsman Closing the Inquiry into Complaint 119/2015/PHP on the European Commission's Handling of a Request for Public Access to Documents Related to TTIP. http://www. ombudsman.europa.eu/en/cases/decision.faces/en/6126l/html.bookmark. Accessed 4 October 2016.

Peterson, J. (2017). Juncker's Political European Commission and an EU in Crisis. Journal of Common Market Studies, 55(2), 349-367.

Stacey, J., \& Rittberger, B. (2003). Dynamics of Formal and Informal Institutional Change in the EU. Journal of European Public Policy, 10(6), $858-883$. 